\title{
Проектирование и изготовление гиперспектральной камеры для беспилотных летательных аппаратов
}

\author{
М.В. Агринский ${ }^{1)}$, К.Б. Горбачев ${ }^{2)}$, В.В. Олейников ${ }^{3)}$, В.В. Старцев ${ }^{1)}$ \\ ${ }^{1}$ Акционерное общество «Оптико-механическое конструкторское бюро «АСТРОН», \\ Московская область, г. Лытткарино, 140080, ул. Парковая, 1 \\ тел./факс: +7 (495) 941-6272, эл. почта: $\underline{v @ a s t r o h n . r u ~}$ \\ ${ }^{2}$ ОКТБ «Омега», г. Великий Новгород. 173003, ул. Саши Устинова, 1 \\ ${ }^{3}$ Технический центр «Инженер», Москва, 129343, пр-д Серебрякова, 6
}

DOI 10.34077/RCSP2019-142

Для осуществления гиперспектральной съемки разработан и изготовлен базовый опытный образец гиперспектральной камеры. Адаптированные для выполнения любых целевых задач в различных областях цифровой экономики гиперспектральные камеры (ГСК) в результате модернизации базового образца могут производить съемку с высоким спектральным разрешением в УФ, ВД и ИК диапазонах спектра. [1,2]

В процессе проектирования проведен технический анализ компонентов ГСК:

- назначению, области применения, основным решаемым задачам и техническим характеристикам камеры телевизионной (КТ) для гиперспектральной камеры;

- анализу основных технических характеристик фотоприемников для оптических систем технического зрения и выбору типа преобразователя свет-сигнал для (КТ);

- структурной схеме и принципу действия (КТ), взаимодействия с сопрягаемыми изделиями, конструкции прибора;

- расчетам, подтверждающим заложенные в (КТ) технические характеристики, расчетам полей зрения, углового и линейного разрешения, освещенности на матрице, ширины полосы съемки земной поверхности и т.д.;

- вариантам реализации системы стабилизации изображения и перспективам развития гиперспектральных систем;

- программному обеспечению (ПО) ГСК, включая обработку информации внутри ПЛИС логики камеры, выбору технологии видеозахвата и написание ПО;

-проектированию системы накопления данных;

- оптического блока, состоящего из объектива и спектрального блока.

В силу специфики работы объектива целесообразно, чтобы он имел вынесенный входной зрачок, что и обеспечено в полученной схеме. Вынос входного зрачка (апертурной диафрагмы) объектива в данном случае составляет 11,34 мм. Другой особенностью объектива является требование телецентрического хода лучей. Данное требование обеспечено выбором оптической схемы объектива, который представляет собой обратный телеобъектив. Параксиальные характеристики и конструктивные параметры рассчитанной системы следующие: $\mathrm{F}^{\prime}=50 \mathrm{mм}, 2 \mathrm{w}=10 \mathrm{O}, \mathrm{F} / \#=2,7$. Объектив обеспечивает контраст на уровне не ниже 0,2 на пространственных частотах до 300 лин/мм, что соответствует требованиям, определяемым выбранным приёмником излучения. Оптическая схема спектрального блока с плоской дифракционной решёткой, где роль коллиматорного и изображающего объектива выполняют одинаковые внеосевые зеркально-линзовые объективы типа Максутов-Ньютон.

\section{Лuтература}

[1] Гонсалес Р. Вудс Р. Цифровая обработка изображений / Пер. с англ. под ред. Чочиа П.А. - М.: Tехносфера, 2005, $1072 \mathrm{c}$.

[2] J.C. Brailean, R.P. Kleihorst, S. Efstratiadis, A.K. Katsaggelos, R.L. Lagendijk, Noise Reduction Filters for Dynamic Image Sequences: A Review // Proceedings of IEEE, vol. 83, no. 9, pp. 1272-1292. 